\title{
Study of Community Perception on Drinking Water Quality in Mogadishu, Somalia
}

\author{
Mohamed Ibrahim Abdi-Soojeede, Mohamed Ahmed Kullane
}

University of Somalia (Uniso), Mogadishu, Somalia

Email: drsoojeede@gmail.com

How to cite this paper: Abdi-Soojeede, M.I. and Kullane, M.A. (2019) Study of Community Perception on Drinking Water Quality in Mogadishu, Somalia. Open Journal of Applied Sciences, 9, 361-371. https://doi.org/10.4236/ojapps.2019.95030

Received: April 10, 2019

Accepted: May 21, 2019

Published: May 24, 2019

Copyright $\odot 2019$ by author(s) and Scientific Research Publishing Inc. This work is licensed under the Creative Commons Attribution International License (CC BY 4.0).

http://creativecommons.org/licenses/by/4.0/

\begin{abstract}
The objective of this study is to determine the community perception on drinking water quality in Mogadishu, Somalia. Researchers tried to declare quality of water in Mogadishu, and if they are aware source of pollution of waters. The study provided a description of a variety of aspects related to perceptions of drinking water in Mogadishu community of Somalia. Method: The study area was people living the capital city of Somalia, Mogadishu, and some academic students irrespective of districts which they live. This study was descriptive research with specifically cross-sectional survey using designed questionnaire added interpretation to local Somali language. The target population was 65 individuals, but researchers made sample size calculation using confidence interval and confidence level. After that, we got sample size 52 individuals. The sample procedure was non-probability purposive sampling. The data analyzed method was descriptive research, with mean and standard deviation, with using software SPSS version 16 applied in this study. Result: The results of Table 10 showed: $71.7 \%$ of respondents strongly agreed and agreed (45.3\% and $26.4 \%$ respectively) that Good water quality is very important issue, with mean score 2.02 out of 5 . Also $73.5 \%$ of respondents accepted (35.8\% strongly greed and $37.7 \%$ agreed) they worried about water quality in Benadir region with mean score 2.04 out of 5 . The respondents were asked questions related to perception of water quality by rating it. The majority respondents $(30.2 \%)$ rated the overall water quality of their local wells as "Good"; some of them (28.2\%) perceived water quality as "Adequate or Normal". This questions has mean score (2.70 out of 6 ) and standard deviation (1.265). Of respondents, they rated the quality of their drinking water. The majority (32.1\%) perceived quality of water is "Good" and has not reached excellent; $28.2 \%$ of them selected "Adequate or Normal"; $18.9 \%$ believed their drinking water is "Poor"; and last $15.1 \%, 1.9 \%$ and $3.8 \%$ of them selected "Very Poor", "Excellent" and "I Don't Know" respectively. This
\end{abstract}


question has mean score (2.98 out of 6) and standard deviation (1.248).

Recommendation: Researchers recommend transferring all wells from resident area to outside the city to prevent contamination of toilet, and must be announced committee that can make generalized water test of local wells and to count borehole wells.

\section{Keywords}

Community, Perception, Water Quality, Mogadishu, Somalia

\section{Introduction}

The objective of this study is to determine the community perception on drinking water quality in Mogadishu, Somalia. Researchers tried to declare quality of water in Mogadishu, and if they are aware source of pollution of waters. This study was significant to mobilization of population for the use quality of drinking water.

The study provided a description of a variety of aspects related to perceptions of drinking water in Mogadishu community of Somalia. The outcomes have directly connected the Ministry of Health of local and state authority, to take action for implementation of development and management of water projects with Benadir Region Somalia.

\section{Literature}

The Water sources in Somalia are dominated by surface water in general. The two permanent rivers are the Shabelle and Juba rivers. Rivers come from Ethiopia; the second source in Somalia is groundwater which can be table water wells (shallow wells) and aquifer waters wells [1].

The Somalia has got recently new recognized federal government, passed with second presidential election, but still it has not ability to fund and distribute safety and pure water to its citizens, so the majority of water source companies are local investor-owned operations with local business people as shareholders, except Somaliland and Puntland they have only operational Public water service. Some companies have performed better than expected, particularly in the cities of Boroma, Bosasso and Jowhar [2].

Unfortunately, these local water supply companies in Mogadishu have built in the local residential areas, which have latrines near water sources. So there is relationship between ground water contamination and downstream of latrine contents; Graham, J. P., \& Polizzotto, M. L. (2013), found groundwater contamination is frequently observed downstream of latrines, contaminant transport distances, recommendations based on empirical studies, and sitting guidelines are variable and not well aligned with one another [3].

There is availability of improved water supply to small companies which 
processed the water for purification and then sold as per liters, which are very expensive to all communities. They package in bottles and other plastic materials. There is no other facilitators and lack of maintenance of water sources and supply systems. This has resulted in only 45 per cent of the population having access to improved water sources [4].

\subsection{Water and Health}

UNICEF Somalia and FSNAU Have tried for mapping of access to water and sanitation and the data collected during FSNAU household surveys in 2009 and 2010 shows a close correlation between areas of high malnutrition and areas with poor access to water and sanitation [4]. The water-related Diseases concern mostly shortage of water both surface and ground water, as FAO reported (2005), In Mogadishu the water supply is affected by saltwater intrusion from the sea because of extensive groundwater pumping [1].

\subsection{Perception of Drinking Water}

Mostly the perception is different form community to community, Hendri Coetzee et al. (2016), they revealed that most residents understood the quality of water to relate to aspects like the clarity and colour (cleanliness and brightness), as well as smell and composition and also they found Participants were requested to rate the quality of the water in their communities [5]. The majority (72.4\%) regarded the water quality in their area as "average", with a smaller group $(24.9 \%)$ perceiving their water as being of "good quality". Very few participants felt that their water quality was either "poor" $(2.5 \%)$ or "excellent" $(0.5 \%)$.

Rojas L et al. 2013, found that the main factors influencing peoples' water quality perception are its colour and appearance, which form a sort of "quality standard" used to evaluate the water quality, even of raw water. The use of raw water for hygiene practices and irrigation is not perceived as a potential risk [6].

\section{Methods}

\subsection{Study Area}

The study subjects were people living the capital city of Somalia Mogadishu, and some academic students irrespective of Districts which they live. Mogadishu which is the capital city of Somalia and located in Benadir region, the Benadir has seventeen districts. The respondents are most visited streets and academic areas near campuses of University of Somalia (Uniso), Unsi has three campuses located in different districts (Hodon, Howlwadaag and Warta nabada) and mostly academic students are the only persons who will give you really the actual situation in the community, mostly they accept the interview and questionnaires. 


\subsection{Study Time}

This study time was performed in December 2018, until March 2019, four months, seasonally it was late Deyr (raining) season up to Jilal (dry) seasons.

\subsection{Study Design}

The study was used descriptive research with specifically cross sectional survey using designed Questionnaires of community perception on Drinking water quality added interpretation to local Somali language, to make easily understandable; then distributed to all respondents. The Questionnaires was evoked but some of them were taken Hendri Coetzee et al. 2016 [5].

\subsection{Sample Size}

The target population was 65 individuals, but researchers made sample size calculation using confidence interval and confidence level. After that we got sample size 52 individuals. The sample procedure was non probability Purposive sampling.

\subsection{Data Analysis}

The data analyzing methods was used Descriptive research, with Mean and standard deviation, with using software SPSS version 16 was applied in this study.

\section{Result of Study}

\subsection{Demographic Data}

The water quality is a very important issue on every communities, because lack of quality water will cause illness and death to all susceptible groups, some this study was discovers the perception of water quality to undergraduate and postgraduate students in Mogadishu Somalia.

Before we discussed the data first we mention the demographic characteristics of respondents; Table 1 showed four Questions (Gender, Age, Marital and Education) which were the demographic data of the respondents. The sample was 52 persons encompasses with Students (Undergraduate and Postgraduate), and some of lecturers. Majority of Sex group of the respondents were $75.5 \%$ of males and $24.5 \%$ of females. Majority of the respondents' age were in between $25-30$, $58.5 \%$. And $30.2 \%$ were in between 20 - 25 years old, 9.5\% were in between 30 35 and the remaining $1.9 \%$ were more than 50 years old. In addition, majority of the respondent's marital status (73.6\%) were Single, while the other $26.4 \%$ were married. This result showed that the majority of respondents were Single because they are mostly students.

Table 1, last section, the Education level of Respondents, the Majority of them $71.7 \%$ was Bachelor (some of them are under process of bachelor or Undergraduate), $17 \%$ were Secondary, and while $11.3 \%$ was Master Degree. Furthermore there senior students of undergraduate mostly they selected bachelor because 
Table 1. Demographic data.

\begin{tabular}{|c|c|c|c|}
\hline \multicolumn{4}{|c|}{ Sex } \\
\hline & Frequency & Percent & Cumulative Percent \\
\hline Male & 40 & 75.5 & 75.5 \\
\hline Female & 13 & 24.5 & 100.0 \\
\hline Total & 53 & 100.0 & \\
\hline \multicolumn{4}{|c|}{ Age } \\
\hline & Frequency & Percent & Cumulative Percent \\
\hline $20-25$ & 16 & 30.2 & 30.2 \\
\hline $25-30$ & 31 & 58.5 & 88.7 \\
\hline $30-35$ & 5 & 9.4 & 98.1 \\
\hline 50 above & 1 & 1.9 & 100.0 \\
\hline Total & 53 & 100.0 & \\
\hline \multicolumn{4}{|c|}{ Marital status } \\
\hline & Frequency & Percent & Cumulative Percent \\
\hline Single & 39 & 73.6 & 73.6 \\
\hline Married & 14 & 26.4 & 100.0 \\
\hline Total & 53 & 100.0 & \\
\hline \multicolumn{4}{|c|}{ Educational level } \\
\hline & Frequency & Percent & Cumulative Percent \\
\hline Secondary & 9 & 17.0 & 17.0 \\
\hline Bachelor & 38 & 71.7 & 88.7 \\
\hline Master & 6 & 11.3 & 100.0 \\
\hline Total & 53 & 100.0 & \\
\hline
\end{tabular}

Source: Primary data.

they hope to graduate near months, that why Bachelor is the Majority of total respondents of educational level.

\subsection{Reliability of Data}

The reliability of data relating of Table 2 was 0.717 Cronbach's alpha, which indicates reliability of consistency of questionnaires data of the study. Only calculated direct related questions based on rates not added demographic characteristics and affirmative questions.

\subsection{Rating of Water Quality}

In Table 3, the respondents were ask you questions relating perception of water quality by rating it, first question was; Rate the overall water quality of local wells, the rate scale of this was; Very poor, Poor, adequate, Good, Excellent and I Don't know, the majority (30.2\%) were regarded the water quality in their 
Table 2. Reliability statistics.

\begin{tabular}{cc}
\hline \multicolumn{2}{c}{ Reliability Statistics } \\
\hline Cronbach's Alpha & N of Items \\
\hline 0.717 & 13 \\
\hline
\end{tabular}

Table 3. Rate the overall water quality of local wells.

\begin{tabular}{|c|c|c|}
\hline \multicolumn{3}{|c|}{ Rate the overall water quality of local wells } \\
\hline & Frequency & Percent \\
\hline Very poor & 14 & 26.4 \\
\hline Poor & 7 & 13.2 \\
\hline Adequate & 15 & 28.3 \\
\hline Good & 16 & 30.2 \\
\hline I don't know & 1 & 1.9 \\
\hline Total & 53 & 100.0 \\
\hline \multicolumn{3}{|c|}{ Rate the quality of your drinking water } \\
\hline & Frequency & Percent \\
\hline Very poor & 8 & 15.1 \\
\hline Poor & 10 & 18.9 \\
\hline Adequate & 15 & 28.3 \\
\hline Good & 17 & 32.1 \\
\hline Excellent & 1 & 1.9 \\
\hline I don't know & 2 & 3.8 \\
\hline Total & 53 & 100.0 \\
\hline \multicolumn{3}{|c|}{ Rate the overall Quality of other pure water companies } \\
\hline & Frequency & Percent \\
\hline Very poor & 6 & 11.3 \\
\hline Poor & 10 & 18.9 \\
\hline Adequate & 12 & 22.6 \\
\hline Good & 14 & 26.4 \\
\hline Excellent & 8 & 15.1 \\
\hline I don't know & 3 & 5.7 \\
\hline Total & 53 & 100.0 \\
\hline
\end{tabular}

area "Good", with second groups (28.2\%) were perceiving water quality as being "Adequate or average", the third groups (26.4\%) were selected water quality as "Very Poor", very small number were selected (Poor) with (13.2\%) and only $(1.9 \%)$ means one person was selected "I don't know". This questions has Mean score in Table 4 (2.70 out of 6) and standard deviation (1.265).

The second question (Table 3 ) relating rating perception of water quality was; Rate the quality of your drinking water, it has similar rating scale as first 
Table 4. Descriptive statistics.

\begin{tabular}{ccccccc}
\hline \multicolumn{7}{c}{ Descriptive statistics } \\
& N & Minimum & Maximum & Mean & Std. Deviation \\
\hline $\begin{array}{c}\text { Rate the overall water quality of local wells } \\
53\end{array}$ & 1 & 6 & 2.70 & 1.265 \\
$\begin{array}{c}\text { Rate the quality of your drinking water } \\
\text { Rate the overall quality of other pure } \\
\text { water companies }\end{array}$ & 53 & 1 & 6 & 2.98 & 1.248 \\
Valid n (listwise) & 53 & 1 & 6 & 3.32 & 1.397 \\
\hline
\end{tabular}

question. The Majority (32.1\%) were perceived quality of water they drink (Good), not reached excellent, (28.2\%) were selected (adequate), (18.9\%) of respondent were believed their drinking water was (Poor), (15.1\%) of them were selected (very Poor), and the last two groups were (1.9\%) with excellent and $3.8 \%$ ) were selected (I don't know). This questions has Mean score in Table 4 (2.98 out of 6 ) and standard deviation (1.248).

The third question (Table 3) was; Rate the overall Quality of other pure water companies, (26.4\%) was majority of respondents were believed "Good", (22.6\%) were perceived "adequate", (18.9\%) were chosen "Poor", (15.1\%) were actual selected "Excellent", some of the respondents (11.3\%) were selected (very poor), and last group (5.7\%) were selected (I don't know). This questions has Mean score (3.32 out of 6) and standard deviation (1.397) (Table 4).

\section{The color of water}

The color of water that they drinking was asked, in below Table 5, the majority $(71.7 \%)$, were responded Normal color (means colorless), but there is second points $(20.8 \%)$ were responded "shadow". There were also two some other color that seen in the some districts but the water does not use drinking but used as other needs. (3.8\%) were grey color and (3.8\%) were green color.

\section{The Smell of water}

In below Table 6, the smell of local water was important and asked the respondents, the Majority (67.9\%) were said "No have odor", that was normal, and very small number $(32.1 \%)$ were selected yes, but the odor was like clay or hot clay odor.

\section{The presence of floating in water}

The floating in water was common the tape water when compared to Distilled water, Table 7; the Majority (54.7\%), were responded "Yes" which means yes there was presence of floating in water, the second group (45.3\%) were responded "No" which was No floating in water.

\section{The taste of water}

The taste of water have vital in how much volume can each person drink, so Table 8; the majority (67.9\%) were said "Good taste", (20.8\%), of the respondents were said "Fair taste" and last group (11.3\%) were said bad taste.

\section{The type of water they drink}

The respondent were asked type of water they drink, in Table 9; the Majority 
Table 5. Color of water.

\begin{tabular}{ccc}
\hline & Color of water & \\
\hline & Frequency & Percent \\
\hline Normal & 38 & 71.7 \\
Shadow & 11 & 20.8 \\
Grey color & 2 & 3.8 \\
Green color & 2 & 3.8 \\
Total & 53 & 100.0 \\
\hline
\end{tabular}

Table 6. Smell.

\begin{tabular}{ccc}
\hline & Smell & \\
\hline & Frequency & Percent \\
\hline No smell & 36 & 67.9 \\
Have odor & 17 & 32.1 \\
Total & 53 & 100.0 \\
\hline
\end{tabular}

Table 7. Presence of floating and precipitating.

\begin{tabular}{ccc}
\hline & Presence of floating and precipitating \\
\hline & Frequency & Percent \\
\hline Yes & 29 & 54.7 \\
No & 24 & 45.3 \\
Total & 53 & 100.0 \\
\hline
\end{tabular}

Table 8. Taste of drinking water.

\begin{tabular}{ccc}
\hline & Taste of drinking water \\
\hline & Frequency & Percent \\
\hline Bad & 6 & 11.3 \\
Fair & 11 & 20.8 \\
Good & 36 & 67.9 \\
Total & 53 & 100.0 \\
\hline
\end{tabular}

Table 9. Type of water you drink.

\begin{tabular}{ccc}
\hline & Type of water you drink & \\
\hline & Frequency & Percent \\
\hline Bottle drinking water & 10 & 18.9 \\
Drinking tap water & 31 & 58.5 \\
Filter tap water & 12 & 22.6 \\
Total & 53 & 100.0 \\
\hline
\end{tabular}


(58.5\%) of them were selected "tape water" unfiltered, (18.9\%) were said they drink bottle water means Distilled water, and (22.6\%) were said filtered Tape water, which means tape water user of the total respondents were $(81.1 \%)$.

\subsection{Other Perception Related to Water Quality}

The results of Table 10, showed, $71.7 \%$ most of respondents strongly agreed and agreed (45.3\% and $26.4 \%$ respectively) that Good water quality is very important issue, with mean score 2.02 out of 5 . As well as the $73.5 \%$ of Respondents accepted (35.8\% strongly greed and $37.7 \%$ agreed) they worried about water quality in Benadir region with Mean score 2.04 out of 5. Furthermore, $54.7 \%$ of the respondents were strongly agreed and agreed that they willing to pay more money or fees to protect or preserve water quality with mean score 2.45 out 5 . It proposed that the quality of water in local area is affected by toilet digged near wells and $58.5 \%$ of the respondents strongly agreed and agreed $(34.0 \%$ and $24.5 \%$ respectively), with mean score 2.28 out of 5 .

The respondents answered that actions that they take can affect the quality of their drinking water with $49 \%$ strongly agreed and agreed but $32.1 \%$ of the respondent answered neutral. With mean score 2.57 out of 5, and As well as $60.3 \%$ of them strongly agree and agree (37.7\% strongly agree and $22.6 \%$ agree), have taking actions to protect the quality of drinking water of their homes and some selected (26.4\%) in Neutral. mean score 2.21 out of 5

\section{Discussion and Conclusion}

This research examined perception of water quality. It seems to be an important issue to address how academic and some community member believed water quality. Therefore, this study aimed at studying the perception of water quality in Mogadishu, Somalia. The study found three sections in data analysis,

Table 10. Descriptive statistics.

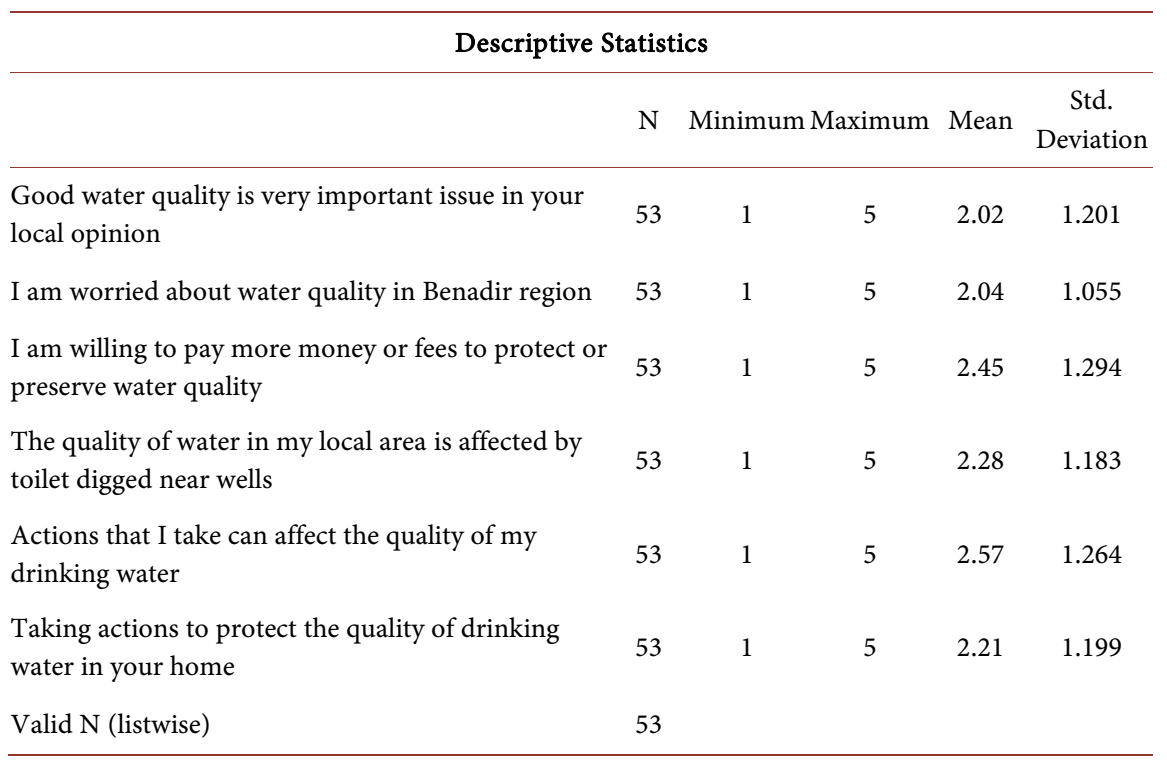


including physical appearance of local, rate of local water and other water related issues, but if added demography, it will be four sections.

The physical appearance of water includes color, smell, taste, floating particles and kind of water (tape water and bottle water, distilled water). Researchers get that local drinking water has normal color, and no odor or smell at all, except that some have clay like odor; taste of tape water is Good; some have faire and bad taste as mentioned (Table 8); also drinking water has small floating particles in it. And the source of mostly drinking water for local community was tape water, but there were other respondents using bottle water.

The overall water quality of local wells was good and adequate (normal), because most of the communities use tape water as source of their drinking water. The rating of the quality of their drinking water was good, but some of them selected "normal, poor and I don't know". The last question was rating the overall quality of other pure water companies. The respondents selected "Good, Adequate and Excellent", but the excellent was the last rank (with low percentage), because community does not use mostly pure water. Some of them believed that pure water (bottle water) will cause constipation.

The final section was related to water quality. Most of respondents strongly agreed and agreed that Good water quality is very important issue, so every human being knew water is life. The respondents worried about water quality in Benadir region, which means that there was water scarcity on some neighborhood regions in benadir regions, such as Lower shabelle (Jowhar), and Middle shabell including Afgoye [7]. The respondents strongly agreed that they are willing to pay more money or fees to protect or preserve water quality. Also, the important issue about contamination of water was source pollution of water wells. The respondents answered the quality of water in local area is affected by toilet digged near wells. The respondents strongly agreed and agreed that there were local wells digged near toilet. Also the respondents answered that actions that they take can affect the quality of their drinking water with "strongly agree and agree" with high percentage, which means they have attention to control any exposures that can contaminate their water. The respondents took actions to protect the quality of drinking water of their homes, because they participated in the protection process of water quality in homes.

\section{Recommendations}

This study suggested points needed to be aware to protect the quality and quantity of local water. There was no strong government authority having ability of distributing quality water, even though there are some regions that have faced water scarcity. Researchers recommended the following points:

- Researchers recommended transferring all wells from resident area to outside the city to prevent contamination of toilet.

- The government must be announced committee that can make generalized water test of local wells and to count borehole wells. 
- There must be continued surveillance of quality of water in Benadir region.

- The health officers must make mobilization of water preserving, protecting and maintaining quality.

- The health officer must check drinkable water wells and non-drinkable.

The researchers that are ready to undertake further studies in this area are advised to investigate chemical components on drinking water, contamination source of drinking water and parasites on drinking water.

\section{Acknowledgements}

We would like to acknowledge all respondents, and colleagues those worked with us, particular Mr. Ahmed Mohamed Farah (Kulmie), all lecturers of faculty of agriculture, University of Somalia (Uniso).

\section{Conflicts of Interest}

The authors declare no conflicts of interest regarding the publication of this paper.

\section{References}

[1] FAO (2005) Somalia Water Report 29, 2005. http://www.fao.org/nr/water/aquastat/countries_regions/SOM/

[2] USAID (2010) Somalia Water and Sanitation Profile. http://www.washplus.org/sites/default/files/somalia2010.pdf

[3] Graham, J.P. and Polizzotto, M.L. (2013) Pit Latrines and Their Impacts on Groundwater Quality: A Systematic Review. Environmental Health Perspectives, 121, 521-530. https://doi.org/10.1289/ehp.1206028

[4] UNICEF Somalia "Water, Sanitation and Hygiene". https://www.unicef.org/somalia/wes.html

[5] Coetzee, H., Nell, W. and Bezuidenhout, C. (2016) An Assessment of Perceptions, Sources and Uses of Water among Six African Communities in the North West Province of South Africa. Water SA, 42, No. 3. https://doi.org/10.4314/wsa.v42i3.08

[6] Rojas, L.F.R., Megerle, A. and Araral, E. (2013) Perception of Water Quality and Health Risks in the Rural Area of Medellín. American Journal of Rural Development, 1, 106-115.

[7] Abdi-Soojeede, M.I. (2018) Crop Production Challenges Faced by Farmers in Somalia: A Case Study of Afgoye District Farmers. Agricultural Sciences, 9, 1032-1046. https://doi.org/10.4236/as.2018.98071 